\title{
Baśń w biblioterapii integralnej
}

\section{Fairy tales in integral bibliotherapy}

Abstract: This text's main objective is to introduce the assumptions of the Jungian depth psychology to the bibliotherapeutic process. Bibliotherapy as an interdisciplinary method using psychology and literary studies enriched with the theory of integral psychology formulates a new theoretical perspective and constitutes a proposition of holistic view of bibliotherapy. The extension of the theoretical basis of bibliotherapy will help to augment the therapeutic effect, activate the unconscious (the sphere neglected in school education), and strengthen psyche. Integral bibliotherapy shall create conditions to expand the dialogue between the rational side and unconscious one, and it will contribute to a positive stimulation of the integration processes. Providing archetypal patterns reflecting the rules of life in culture, and drawing attention to the regulatory role of literary works, will enrich both the intellectual and spiritual side of the development of the participant of the bibliotherapeutic process. Archetypal content present in literary texts studied by the participant according to the bibliotherapeutic procedure will achieve an integral orientation focused on the humanistic dimension of existence.

Keywords: bibliotherapy, depth psychology, unconsciousness, archetypes, identification, catharsis, insight, symbol, individuation

Biblioterapia korzysta $\mathrm{z}$ utworu literackiego w celu wywołania pożądanych zmian w psychice, zmierza do osiągnięcia efektu terapeutycznego, zbudowania zasobów osobistych (Molicka, 2011; Borecka, 2001), a jako metoda interdyscyplinarna, skupiona na poprawie jakości życia człowieka, realizuje doświadczenia nauk psychologicznych i przede wszystkim odwołuje się do psychologii sztuki, psychologii rozwoju człowieka, psychologii klinicznej, psychologii literatury (Czernianin, 2008, s. 91). W tym świetle termin biblioterapia integralna stanowi propozycję realizacji w procesie biblioterapeutycznym Carla Gustava Junga założeń psychologii głębi i wskazuje holistyczny kierunek biblioterapii, zmierzającej do procesu indywiduacji jednostki. W biblioterapii integralnej proces terapeutyczny będzie się odnosił do zasadniczych modeli Jungowskich: nieświadomości i świadomości, archetypów, koncepcji dzieła wizjonerskiego (Dudek, 2007, 
s. 251). Włączenie energii archetypów do działań biblioterapeutycznych wzbogaci teoretyczną strukturę biblioterapii, wprowadzi nową perspektywę do podstaw naukowych omawianej dyscypliny (Czernianin, Czernianin, 2012, s. 5).

\section{Literatura wizjonerska}

Według Junga, w literaturze, szczególnie wizjonerskiej, odbija się przestrzeń zbiorowej nieświadomości, dzięki czemu może ona wpływać na wewnętrzne życie ludzkości, wprowadzać na duchową ścieżkę. Literatura wizjonerska ma wiele wspólnego z pierwotnym doświadczeniem przekraczającym rozumienie człowieka, jest wizją, którą artysta pragnie wyrazić. Jak pisze Zofia Rosińska, „przy doświadczeniu wizjonerskim jesteśmy zdziwieni, zaskoczeni, nawet zdegustowani. [...] Nic $\mathrm{z}$ treści wizji nie jest nam znane z doświadczenia codziennego; podobieństwa szukać raczej należy w nocnych lękach, koszmarach sennych" (Rosińska, 1982, s. 89). Literatura wizjonerska, cechując się bogactwem symboliki archetypowej, odwołuje się do kulturowych przedstawień, a uniwersalne obrazy literackie odsyłają do sfery nieprzemijalnego bytu, nieświadomych źródeł życia. Wydaje się, iż w tego typu ujęcia wpisuje się literatura baśniowa, cechująca się energią symbolu stanowiącego esencję literatury wizjonerskiej. W fabułach baśniowych zobrazowane przeżycia są odzwierciedleniem doświadczeń archetypowych, podporządkowane powszechnemu doświadczeniu, osobista psychologia staje się uniwersalna (Wais, 2006). Jung podkreśla ogromną rolę symbolu w procesie wzrastania, budowania zasobów osobistych, konstruowania osobowości. Obecność składników archetypowych w strukturze symbolu stanowi o jego uniwersalnej, transcendentnej wartości, funkcjonującej w świecie baśni, mitów, w dziełach artystycznych oraz całokształcie życia kulturalnego. Obrazy baśniowe eksponujące treści archetypowe, transponowane z pokolenia na pokolenie, budują komponenty kulturowej tradycji, a ich wpływ na rozwój osobowy pozostaje niezmiennie aktualny. Fabuły baśniowe współuczestniczą w zdobywaniu dobrostanu, są użyteczne w konstruowaniu ludzkiej psychiki, a ich terapeutyczny aspekt szczególnie docenił Bruno Bettelheim (Bettelheim, 1985). W ujęciu autora klasycznej książki Cudowne i pożyteczne... baśń, będąca formą prostą, jest symbolicznym odzwierciedleniem dziecięcej psychiki, jej fabuła to obrazowe przedstawienie duszy dziecka, niepotrafiącego jeszcze w sposób werbalny wyrazić procesów wewnętrznych. Odnosząc się do Freudowskiej metody analizy, odkrywa Bettelheim wieloaspektowe znaczenie narracji baśniowych, wskazuje pożytek docierania do ukrytych pod zewnętrzną warstwą, palimpsestowych znaczeń i powiązania ich z osobistymi doświadczeniami. Jung w Fenomenologii ducha $w$ baśniach ukazuje odbiorcy symboliczną rzeczywistość obrazów baśniowych, manifestujących psychiczne procesy, a interpretując je, posługuje się metodami fenomenologicznymi i hermeneutycznymi (Jung, 1981). 
Według Junga, interpretacja dzieła wizjonerskiego nie powinna zaczynać się od intelektualnego odbioru, nie wpłynie to bowiem pozytywnie na rozwój psychiczny podmiotu, a nawet może stać się niebezpieczne dla bezpośredniego doświadczenia. Odbiorca winien się poddać fascynującemu działaniu artystyczno-emocjonalnemu, które rodzi się $\mathrm{w}$ rezultacie zetknięcia się $\mathrm{z}$ energią archetypu, „Wyzwala w nas głos silniejszy od naszego" (Jung, 1981, s. 398).

W intuicyjny model odczytania utworu literackiego wpisują się dzieci, nieświadomie reagujące na zakodowane $\mathrm{w}$ narracji symbole i samoistnie wzbogacające o ich treść przestrzeń psychiczną (Molicka, 2011, s. 170-221). Intuicyjny odbiór baśni, wpisany w osobowość dziecka, stanowi istotny etap dynamiki indywiduacji, procesu scalania psychiki (Śliwierski, 2010). Spontaniczne podleganie treściom archetypowym to terapia przebiegająca początkowo poza świadomością, istotne jest włączenie energii symboli w przestrzeń psychiki, a to właśnie dokonuje się $\mathrm{w}$ trakcie spotkania podmiotu $\mathrm{z}$ utworem baśniowym. James Hillman, poszukując uzdrowienia sytuacji duchowej współczesnego człowieka, zwrócił uwagę na mityczne obrazy reprezentujące autentyzm przeżyć i doświadczeń. Wyrażał przekonanie, że wsłuchując się w narracje mityczne, możemy przywrócić sens naszemu istnieniu. Zdaniem Hillmana, duszy nie trzeba leczyć (dlatego sam zrezygnował z pracy psychoterapeuty), duszę powinno się ożywiać, pielęgnować dzięki przeżywaniu obrazów mitycznych, przyswajaniu i ich wewnętrznemu przepracowywaniu (Hillman, 1996; Hillman, 2014). Zdaniem Maud Bodkin, wzorce archetypowe prowadzące do głębokiego przeżycia literackiego, zanim przeniknęły do literatury, istniały od wieków w tradycyjnych, ustnych opowieściach, rytuałach, wierzeniach religijnych. Tekst literacki uobecniający obrazy archetypowe, wielkie tematy literatury, np. różnorodne konkretyzacje „tragicznego tematu śmierci lub upadku bohatera”, aktywizuje obszary wyobraźni, czyniąc z odbiorcy dzieła „podmiot przeżywający [...] rozleglejszą całość, z której wydzieliło się to, co znamy jako jaźń jednostkową czy osobową i co trwa w nas jako poczucie, utajone lub czynne, jakiejś większej siły" (Bodkin, 1969, s. 231). Archetypowa interpretacja utworu literackiego umożliwia dotarcie do kolektywnego doświadczenia obecnego w wielkich tematach kulturowych w dziejach, otwiera obrazy zawierające powszechne tematy, które uaktywniają przeżycia trwale towarzyszące ludzkości. Odczytanie archetypowych wzorców i rozpoznanie ich modeli w doświadczeniach bohaterów literackich to proces, który powinien być zainicjowany $\mathrm{w}$ dzieciństwie, w czasach baśni, prostych form literackich wprowadzających stopniowo, na drodze czytelniczej edukacji, do świata arcydzieła. W utworach baśniowych uobecniają się wielkie tematy literatury, a odnalezienie ich może się odbywać, zgodnie z doświadczaniem dzieła wizjonerskiego i zawartych w nim głębokich przeżyć, dzięki kontemplowaniu, medytowaniu, poddawaniu się, „wejściu w siebie” (Baluch, 1993). Czytelnik uzyskuje w ten sposób, zdaniem Alicji Baluch, pośrednią odpowiedź na pytanie, kim są dla niego literaccy bohaterowie, czym jest ich los w odniesieniu do 
jego przeżyć, doświadczeń, uczuć. Odkrywa, że łączy ich płaszczyzna porozumienia, wspólna przestrzeń, dociera do nowego wymiaru życia (Baluch, 2008).

Archetypowe odczytanie literatury baśniowej pozwala na uchwycenie procesu indywiduacji, który stale dokonuje się w psychice podmiotu dążącego do pogłębienia zakresu Całkowitości. W ujęciu psychologii Jungowskiej celem indywiduacji jest nieustanne zbliżanie się do osiągnięcia doskonałości, co odbywa się na zasadzie łączenia przeciwieństw, pokonywania ograniczeń, konfrontacji ze słabościami, wyzwalania się ze schematów, wewnętrznych zmagań, docierania do osobistego indywiduum, otwarcia na zbiorowość. Indywiduacja nie wyklucza podmiotu ze wspólnoty, lecz do niej przybliża (Jung, 1994, s. 99), stanowi istotne wyzwanie etyczne, wiążące się z odpowiedzialnością za los własny i innych (Piróg, 1999, s. 77), stanowi wieloetapowy proces doświadczania treści archetypicznych w celu osiągania pełni, wyrażającej się w obrazie Jaźni.

Psychika jest obiektem dynamicznym, przepełnionym energią, dążącym do zintegrowania różnorodnych jej aspektów, do pogodzenia przeciwstawnych tendencji: świadomości i nieświadomości zbiorowej, na którą składają się ponadindywidualne instynkty odziedziczone po przodkach, prawzory (archetypy), rzeczywistość psychiczna, mająca status bytu. Archetypy bytujące w nieświadomości zbiorowej stanowią wzorzec, który zostaje wypełniony osobistą treścią. Archetypy są podmiotowi niezbędne do osiągnięcia pełni osobowej, w trakcie której następuje proces adaptacji przez psychikę kolejnych archetypów (Matki, Cienia, Animy i Animusa, Mędrca, Jaźni). W tym procesie istotną rolę odgrywa literatura, a szczególnie baśniowa, ta, która cechuje się bogactwem symboliki archetypowej, odpowiadającej na wrodzoną potrzebę poznania mitu. Utwory baśniowe odsyłają do wskazanego przez Northropa Frye’a wspólnego sensu, do którego dotarcie jest wielkim zadaniem badaczy literatury, a także badaczy ludzkiej psyche (Frye, 2012; Frye, 1969, s. 283-302). Odniesienie wskazanych prawidłowości do kulturowych kontekstów, jak wskazuje Zenon W. Dudek, „wpisuje się w całokształt procesów reaktualizacji archetypów w konkretnej realności psychicznej (jednostka, grupa społeczna) i kulturowej (cywilizacja, epoka)" (Dudek, 2012, s. 146).

W pierwotnych obrazach psychicznych tkwią ich niepoznawalność i autonomiczność, uobecniają się one w życiu psyche niezależnie od stanowiska intelektu. Świadomość, dążąc do wyrażenia duchowych doświadczeń, tworzy symbole, które stanowią obrazowe przedstawienie rzeczywistości psychicznej. Symbol jako wyraz sprzeczności natury ludzkiej jest jednocześnie racjonalny i nieracjonalny, zawiera „aspekt wychodzący naprzeciw rozumowi, ale ma też aspekt rozumowi niedostępny" (Jung, 2013, s. 529); jako najgłębszy wyraz życia psychicznego, zawiera treści duchowe i intelektualne, energię archetypów, a także wiedzę pochodzącą od ego, odnosi się do rozwoju osobowego człowieka, emocji, uczuć, przeczuć, doznań oraz procesu myślowego. 


\section{Biblioterapia integralna a edukacja}

We współczesnej myśli pedagogicznej uobecnia się refleksja dotycząca roli nieświadomości w edukacji, konieczności uwzględniania procesów intuicyjnych w działaniach edukacyjnych. Bernie Neville, odwołując się do badań Freuda, Junga, Hillmana, Ericsona, zwraca uwagę na wielowymiarowy, holistyczny ogląd edukacji. W refleksje te wpisuje się biblioterapia integralna, realizująca postulowany przez Neville'a model posługiwania się nieświadomością w procesie edukacyjnym (Neville, 2009). W realiach szkolnych nie jest łatwo realizować formy pracy odwołujące się do aspektów nieświadomości. Wynika to z jednostronnego ukierunkowania systemu nauczania, odwołującego się przede wszystkim do racjonalistycznego podejścia, a zagadnienia rozwijające wyobraźnię, myślenie intuicyjne, swobodę wypowiedzi zarówno w treści, jak i formie napotykają opór nauczycieli, a także rodziców nastawionych na realizację programu i oceny. Biblioterapia może zatem stać się wartościową formą zdobywania wiedzy o nieświadomości, dziedziną pozwalającą spojrzeć na świat z perspektywy duszy. Zenon Dudek podkreśla, że wielkim błędem utrwalonym w zbiorowej świadomości ludzi Zachodu jest „przekonanie, że człowiek buduje prawdę o sobie i życiu na podstawie świadectwa zmysłów i rozumu oraz że rodzi się z umysłem jak z czystą kartą" (Dudek, 2013, s. 9). Wynikiem takiego podejścia jest niszczenie indywiduum, kreatywności, unikalnej osobowości:

[...] program nauczania ma uczynić z młodego człowieka idealnego obywatela, a przy tym geniusza, który przyniesie pożytek ludzkości i będzie szczęśliwy według kryteriów ustalonej naukowo zasady. [...] Takie podejście w wychowaniu doprowadziło do tragicznego absurdu w systemie nazistowskim i komunistycznym.

Dudek, 2013, s. 10

\section{Etapy postępowania w biblioterapii integralnej}

Biblioterapię integralną można prowadzić zarówno w odniesieniu do diagnozy archetypowej (Dudek, 2007, s. 272), określonej na podstawie konsultacji z psychologiem, nauczycielem, wychowawcą, jak i realizować z wyłączeniem wskazanych konsultacji, co wynika z faktu, że przekaz archetypowy wprowadza w wymiar nieświadomości samoistnie, umożliwia bezwarunkowy i niezależny od podmiotu kontakt z przestrzenią transcendentną. Pośrednikami w owym przekazie są symbole obecne w tekście literackim. Diagnoza integralna opiera się na założeniu, że ludzie odczuwają potrzebę osobistego mitu, pragnienie zmierzania do asymilacji, znoszenia dualizmu podmiotu i przedmiotu, potrzebę harmonii, archetypowego wzorca. Zdaniem Hillmana, 
dusza może się ponownie stać rzeczywistością tylko wówczas, kiedy każdy z nas ma odwagę przyjąć ją jako najważniejszą rzeczywistość własnego życia i zdecydowanie opowiadać się za nią, [a - A.M.] warunkiem powstania ontologii jest to, by każda poddawana analizie osoba broniła swoich doświadczeń swoich symptomów, cierpienia, nerwicy i niewidocznych pozytywnych osiągnięć — wobec świata, który ma je za nic.

Hillman, 1996, s. 114-115

\section{Cel biblioterapii integralnej}

Biblioterapia integralna jest ukierunkowana na archetypiczny odbiór tekstu literackiego, opiera się na założeniu, że uczestnik procesu odczyta w sposób nieuświadomiony energię symbolu, co spowoduje otwarcie na rzeczywistość psychiczną, uznającą doświadczenia duchowe za pełnoprawny element ontologiczny. Konstruowanie postawy wewnętrznej stanowi podstawowy cel postępowania biblioterapeutycznego, $\mathrm{w}$ trakcie którego dojdzie do spotkania $\mathrm{z}$ energią symboli, co wywoła wzrost osobowy. Regulacyjne znacznie nieświadomości pozwala na pozytywne przejście kolejnych etapów życia, okresu dorastania, kryzysów rozwojowych, sytuacji granicznych i w tym względzie biblioterapia integralna okaże się pomocna w odnalezieniu wzorców w sytuacji egzystencjalnych doświadczeń.

Partycypowanie w zajęciach biblioterapeutycznych, budowanych wokół modelu wyznaczonego przez archetypy, które są wpisane w narrację baśniową, umożliwi zrealizowanie potrzeb psychiki odnoszących się do metafizycznych pragnień, do chęci poznawania siebie i świata, co dokonuje się dzięki zrozumieniu i włączeniu sfery archetypalnej, oczekującej na uwolnienie i rozpoznanie, $\mathrm{w}$ świadomy obszar inteligencji.

Nieświadomość, jak pisze Z.W. Dudek, ma charakter samoregulacyjny, a „podstawowa zdolność samoregulacji nieświadomej daje o sobie znać w niespodziewanych sytuacjach, wobec nagłego zagrożenia [...], kiedy kontrola świadoma wystawiona jest na próbę" (Dudek, 2007, s. 261). Prawidłowa transmisja obydwu energii psychicznych buduje osobowość holistyczną o trwałej relacji między nieświadomością i ego oraz jaźnią. W dojrzewaniu osobowym powinny następować stabilizacja samoregulacji nieświadomej oraz jej powiązanie z samoregulacją świadomą.

\section{Model postępowania biblioterapeutycznego}

Model postępowania w biblioterapii integralnej wyznaczają archetypy: Wielkiej Matki, Cienia, Animy i Animusa, Starego Mędrca, Jaźni. Jak już wspomnia- 
no, każde przeżycie inspirowane tekstem symbolicznym jest zarazem doznaniem archetypowym: w psychice dokonują się zaszczepienie archetypu, zniwelowanie sprzeczności i wzrost harmonii. W efekcie doświadczenia archetypów następuje akceptacja siebie, budzi się nadzieja na odnalezienie sensu istnienia, krystalizują się życiowe dążenia.

Model prowadzący do uaktywnienia potencjału archetypu Wielkiej Matki realizowany będzie na zajęciach ogniskujących się na wieloaspektowości wskazanego archetypu: dualizm (dobra i zła matka), kompleks matki, różnorodność typów i przedstawień obrazowych (boginie; zwykłe kobiety; postaci magiczne: wróżki, czarownice; przedmioty związane z płodnością, krągłością, pojemnością; natura i jej przejawy; pojęcia i „rzeczy”, np. ojczyzna, Królestwo Niebieskie, miasto, Kościół). Wskazane obrazy będą istotnym elementem programu biblioterapeutycznego, określą tematykę zajęć zgodnie z założeniem, że „modele postępowania biblioterapeutycznego mogą opierać się na więcej niż jednym programie" (Czernianin, 2008, s. 132).

Model związany z archetypem Animy i Animusa odnosi się do wymiaru kobiecości i męskości. Według Junga, psyche ludzką stanowi androgyne składająca się z kontaminacji nieświadomości (animy) i świadomości (animus). Anima łączona z koncepcją erosa jest upostaciowieniem kobiecości (matki, córki, kochanki) i krystalizuje stanowisko mężczyzn wobec pierwiastka żeńskiego. Animus to psychiczny aspekt mężczyzny w kobiecie utożsamiany z logosem; to czynnik odpowiedzialny za projekcję jakości męskich, wszelkich wyobrażeń związanych z męskością. Animus kobiety przechodzi w jej rozwoju osobowym cztery fazy; są to: „wcielenie” siły fizycznej; pragnienie niezależności, samodzielnej inicjatywy, działania; uosobienie „słowa” (profesor, mistrz); pierwiastek duchowy kształtujący oś między świadomością a nieświadomością.

Literackie przedstawienia Animy i Animusa: księżniczki i księcia, idealnej kochanki i kochanka, kobiety fatalnej i don Juana, uobecniają się w rozlicznych realizacjach baśniowych, w których piękno zewnętrzne, odzwierciedla obraz duszy. Interesujący nas model może wyznaczać tematykę programów: baśniowy obraz animy i animusa (księżniczka i książę jako: „[...] źródło identyfikacji dla dziewcząt i projekcji dla chłopców") (Dudek, 2006, s. 167); piękno zewnętrzne a piękno duchowe; projekcje jako źródło nieporozumień i konfliktów; podejmowanie partnerskich relacji z płcią przeciwną; skutki odrzucenia symbolu Animy; utrwalony w kulturze obraz kobiety kusicielki; męski typ kobiety; nieprawidłowa asymilacja archetypu Animusa.

Archetyp Cienia odnosi się do mrocznego, negatywnego aspektu ludzkiej psyche odpowiedzialnej za zło, pejoratywne uczucia, niskie impulsy, destrukcję, nerwicę, agresję. Jung wyróżnił Cień indywidualny - obszar stłumionych przeżyć, kompleksów, lęków, niepokojów, urazów, oraz Cień zbiorowy manifestowany w obrazach diabła, Tartaru, Hadesu, Szeolu, piekła. Wypracowanie zdolności panowania nad Cieniem dzięki zrozumieniu go i asymilacji umożliwia wykształce- 
nie postawy tolerancji, równowagi, radzenia sobie z emocjami. Pozytywna konfrontacja $\mathrm{z}$ Cieniem pozwala dostrzec $\mathrm{w}$ cierpieniach mądrość wiodącą do rozwoju duchowego, „urazy i przykre doświadczenia bolą, ale także uczą” (Dudek, 2006, s. 150). W przypadku dzieci doświadczających traumatycznych przeżyć dochodzi do przedwczesnego zetknięcia się z Cieniem archetypowym (inicjacji negatywnej), a nieukształtowane ego nie potrafi stawić czoła urazom, które doznane w dzieciństwie kształtują postawę psychopatyczną, neurotyczną, ze skłonnościami do depresji czy schizofrenii (Dudek, 2006, s. 148). Biblioterapia ukierunkowana na sferę Cienia umożliwia jednostce spotkanie z „ciemnym bratem”, z niechcianą, niepożądaną i odrzucaną sferą, pozwala dotrzeć do bolesnych doświadczeń i je przepracować. Programy biblioterapeutyczne odnoszące się do archetypu Cienia powinny uwzględniać problemy związane z zagadnieniem śmierci, cierpienia, kultu przemocy oraz siły fizycznej, ciała, uzależnień, depresji, lęków, manipulowania, kompleksów, projektowania osobistego Cienia na innych.

Archetyp Mędrca wyznacza model zajęć omawiających rolę: mistrza, nauczyciela, proroka, duchowego przewodnika, pustelnika, jasnowidza, tego, który prowadzi, wskazuje drogę i bezpieczne miejsce, wspiera, dodaje sił, pomaga w odnalezieniu najdoskonalszych przejawów bytu. W literaturze baśniowej znajdziemy rozliczne realizacje wspomnianych symboli, a odnoszą się one głównie do zdarzenia fabularnego, w którym bohaterowie literaccy będący w sytuacji granicznej spotykają na swojej drodze postać odznaczającą się duchową inteligencją. Mistrz przekazuje wskazówki, kluczowe dla biografii bohatera nauki, dzięki jego wiedzy bohater wnika w siebie, ma możliwość głębszego poznania siebie, zdobycia nowej wiedzy, dokonuje się jego przemiana. Spotkanie z Wielkim Mędrcem jest konieczne $w$ trakcie indywiduacji, umożliwia i wzbogaca proces rozwoju osi ego - Jaźń.

Archetyp Jaźni jest wyrazem Całkowitości, zjednoczenia przeciwieństw, kontaminacji wymiaru duchowego i materialnego, stanowi ślad Boga w ludzkiej psyche, spełnia funkcję transcendentną i jest przedstawiany w symbolu mandali. Jaźń uobecnia się

w mitach i bajkach w formie „osobowości nadrzędnej”, na przykład w postaci króla, herosa, proroka, zbawiciela i tak dalej [...], czy też jako koło, czworokąt, quadratura circuli, krzyż [...] przejawia się w formie gry yang i yin, jako para braci, heros i jego przeciwnik (smok, wrogi brat, śmiertelny wróg, Faust i Mefistofeles).

Jung, 2013, s. 522

Literackie przedstawienia symbolu Jaźni uzupełnia artystyczne, wielokulturowe obrazowanie struktury mandali, a jej interpretowanie i wykonanie stanowią istotne elementy terapeutyczne umożliwiające głębsze zrozumienie siebie (Jung, 1997, s. 170). 
Tekst literacki

Wybór tekstu literackiego jest istotnym elementem scenariusza biblioterapeutycznego, a zgodnie z założeniami metodologicznymi biblioterapii integralnej podstawę zajęć stanowi utwór baśniowy zawierający obrazy archetypowe.

$\mathrm{W}$ archetypowych obrazach literackich tkwi dobroczynny, terapeutyczny potencjał, toteż nawiązanie z nimi współpracy daje poczucie bycia sobą, spokoju, równowagi, a przede wszystkim zyskuje się pewność, że podąża się w dobrym kierunku (Jung, 1997, s. 154). Zdaniem Junga, odczytywanie symbolicznego sensu obrazów dynamizuje rzeczywistość psychiczną, służy zrozumieniu uniwersalnego charakteru człowieka, prowadzi do zbudowania wiedzy o świecie wewnętrznym, a także do uchwycenia sił regulujących życie społeczne, religijne (Jung, 2011, s. 175). Ewokatywna siła literatury archetypowej uaktywni energię psychiczną konieczną do twórczej egzystencji.

Uczestnicy procesu biblioterapeutycznego, w trakcie którego dokonuje się interpretacji i analizy symbolu uobecniającego się w tekście literackim, odkryją duchowy wymiar bytu. Symboliczne obrazy literackie, wydobyte w procesie odbioru utworu, mają regulacyjny wpływ na psyche, „pomagają zrozumieć sens niewidzialnego świata" (Wais, 2006, s. 59), dynamizują rzeczywistość psychiczną. Ukierunkowany wybór tekstów literackich pozwala na penetrację subiektywnych, niesprecyzowanych obszarów energii psychicznej.

\section{Identyfikacja z bohaterem literackim}

Identyfikacja $\mathrm{z}$ bohaterem literackim wprowadza dialog z postaciami baśniowymi, co pozwala odblokować wypierane doświadczenia, emocje, uczucia. Uczestnik procesu biblioterapeutycznego początkowo nazywa uczucia bohatera, a następnie przenosi je na indywidualne przeżycia i określa je (narracja wewnętrzna). $\mathrm{W}$ dyskursie $\mathrm{z}$ bohaterem otrzymuje komunikaty pozwalające nawiązać współpracę z problemami wymagającymi rozwiązania, zalegającymi w pokładach psyche (Neville, 2009, s. 128; Tomasik, 1994, s. 17). Bohater literacki uosabiający uniwersalne dylematy (archetypowe wzorce) okazuje się kluczem do zrozumienia niewidzialnych procesów, do odkrycia istotnych treści dotyczących rozwoju osobowego. W procesie identyfikacji budowane są wewnętrzne napięcia. Jak twierdzi Dudek,

jeden biegun stanowi ego (podmiot, wykonawca), a drugi cel symbolizowany przez obraz archetypowy. Identyfikacja $\mathrm{z}$ celem, rozpoznawanie go jako własnego wprowadza zmianę w strukturze samego podmiotu — zwykłe podstawowe ,ja" poszerza się o aspekt zbiorowy, archetypowy: ego staje się bohaterem na drodze indywiduacji, czyli uświadamia sobie, a raczej doświadcza siebie jako 
jednostkę, ale też jako bohatera zbiorowego. Wzorzec archetypowy realizuje się w indywidualnej przestrzeni psychologicznej jednostki.

Dudek, 2007, s. 270

\section{Katharsis}

Identyfikacja z bohaterem literackim inicjuje katharsis, wnikliwe przeżycie emocjonalne wynikające ze spotkania emocji ze świadomością i prowadzące do zrozumienia problemu (Molicka, 2011, s. 120). Archetypy spotykają się z ego, następuje przyswojenie obrazu archetypowego, co wyzwala impuls do przemiany psychicznej. Poszerzenie „ja” o aspekt zbiorowy daje poczucie ulgi, przynosi spadek napięcia utrzymującego się w rezultacie spotkania przeciwieństw. Prawdziwe uwolnienie tkwi w przeżywaniu, odblokowaniu tłumionych uczuć i wprowadzeniu ich do świadomości.

\section{Wgląd w siebie}

Etap wglądu - samopoznanie, zrozumienie siebie i innych, włączenie wartości i celów, integracja (Tomasik, 1994, s. 18) - może odpowiadać czwartej fazie terapii wskazanej przez Z.W. Dudka, kiedy to następuje odwrót aktywności „ja” ulokowanej w zbiorowości i skierowanie jej ku perspektywie indywidualnej. Istotna okazuje się osobista integralność obejmująca całość doświadczenia, które symbolizuje archetyp Jaźni. W trakcie tego procesu o charakterze regulacyjnym następuje:

1. Integracja tego, co psychiczne i subiektywne, z tym, co pozapsychiczne i obiektywne (fizyczne, społeczne, kulturowe),

2. integracja aktywności świadomej i nieświadomej (relacja ego - kompleksy i ego - archetypy),

3. integracja aspektu indywidualnego i zbiorowego psyche (relacja ego - Jaźń, ego - persona).

Dudek, 2007, s. 270

Wgląd w przeżycie archetypowe pomaga w zmianie aspektów poznawczych jednostki, prowadzi do rozpoznania sytuacji archetypowej, wskazuje błędy (przeszłość), obecne cele i zdania (teraźniejszość) oraz gotowość do zmian (przyszłość) $)^{1}$.

${ }^{1}$ Model ten można zestawić z G.D. Spache’a propozycją podsumowania procesu biblioterapeutycznego. Na ów model powołuje się E. Tomasik: „»On jest jak ja« lub »ja jestem jak on« przez: »Ja to czuję tak samo jak on « do »Ja mogę to zrobić właśnie tak, jak on to zrobił« albo »Ja mogę to tak- 
Biblioterapia korzysta z narracji baśniowej ujmowanej w kontekście psychologii Junga, wpisuje się w orientację integralną służącą łączeniu doświadczeń, uczuć, emocji, wiedzy. Etapowe przyswajanie kluczowych dla wzrastania podmiotu procesów psychologicznych (macierzyństwo, ojcostwo, męskość, kobiecość, cierpienie, śmierć, transcendencja) zapewni zdrowie psychiczne, a także uczyni własne życie i byt innych pełniejsze. Proponowana metoda stymulująca do rozwoju osobowego stanowi alternatywę dla pragmatycznej i jednostronnej edukacji, a zarazem wpisuje się w koncepcję integrowania wszystkich struktur osobowych.

\section{Literatura}

Baluch A., 1993, Wiersze medytacyjne Joanny Kulmowej, „Polonistyka”, nr 9, s. 564566.

Baluch A., 2008, Od form prostych do arcydzieła, Kraków.

Bettelheim B., 1985, Cudowne i pożyteczne. O znaczeniach i wartościach baśni, Danek D., przeł., Warszawa.

Bodkin M., 1969, Wzorce archetypowe w poezji tragicznej, Mroczkowski P., przeł., „Pamiętnik Literacki”, nr 60/2, s. 211-231.

Borecka I., 2001, Biblioterapia - teoria i praktyka. Poradnik, Warszawa.

Czernianin W., 2008, Teoretyczne podstawy biblioterapii, Wrocław.

Czernianin W., Czernianin H., 2012, Psychologia literatury w świetle biblioterapii, „Przegląd Biblioterapeutyczny", nr 2, s. 5-42.

Dudek Z.W., 2006, Psychologia integralna Junga. Człowiek archetypowy, Warszawa.

Dudek Z.W., 2007, Paradygmat nieświadomości a poszukiwanie psychoterapii integralnej, w: Węgłowska-Rzepa K., Fredericksen D., red., Między świadomościq a nieświadomościa. Współczesność w perspektywie psychologii głębi, Warszawa, s. 251-276.

Dudek Z.W., 2012, Archetypowa interpretacja literatury, w: Fiała E., Piekarski I., red., Psychoanalityczne interpretacje literatury. Freud - Jung - Fromm - Lacan, Lublin, s. $115-154$.

Dudek Z.W., 2013, Psychologia mitów greckich. Prawda symboli i archetypów, Warszawa. Frye N., 1969, Mit fikcja przemieszczenie, Muskat-Tabakowska E., przeł., „Pamiętnik Literacki”, nr 2, s. 283-302.

Frye N., 2012, Anatomia krytyki, Bokiniec M., przeł., Gdańsk.

Hillman J., 1996, Samobójstwo a przemiana psychiczna, Rogalski D., przeł., Warszawa.

Hillman J., 2014, Kod duszy. W poszukiwaniu charakteru człowieka i jego powołania, Korpanty J., przeł., Warszawa.

Jung C.G., 1981, Archetypy i symbole, Prokopiuk J., przeł., Warszawa.

Jung C.G., 1994, Zasadnicze problemy psychoterapii, Reszke R., przeł., Warszawa.

Jung C.G., 1997, Wspomnienia, sny, myśli, Reszke R., przeł., Warszawa.

że zrobić«. Ostatnim krokiem jest: »Zobacz, ja to zrobiłem«. Ten krok jest warunkiem powodzenia biblioterapeutycznego" (Tomasik, 1994, s. 18). 
Jung C.G., 2011, Dynamika nieświadomości, Reszke R., przeł., Warszawa.

Jung C.G., 2013, Typy psychologiczne, Reszke R., przeł., Warszawa.

Molicka M., 2011, Biblioterapia i bajkoterapia. Rola literatury w procesie zmiany zrozumienia świata społecznego i siebie, Poznań.

Neville B., 2009, Psyche i edukacja. Emocje, wyobraźnia i nieświadomość w uczeniu się i nauczaniu, Kościelniak M., przeł., Kraków.

Piróg M., 1999, Psyche i symbol. Teoria symbolu Carla Gustava Junga na tle ujęć porównawczych rzeczywistości symbolicznej, Kraków.

Rosińska Z., 1982, Jung, Warszawa.

Śliwierski B., 2010, Teoretyczne i empiryczne podstawy samowychowania, Kraków.

Tomasik E., 1994, Czytelnictwo i biblioterapia w pedagogice specjalnej, Warszawa.

Wais J., 2006, Ścieżki baśni, Warszawa.

Agnieszka Miernik - doktor habilitowany nauk humanistycznych, literaturoznawczyni, adiunkt na Uniwersytecie Jana Kochanowskiego w Kielcach. Autorka prac poświęconych twórczości dla młodych odbiorców, współredaktora pracy zbiorowej Słowo - dziecko - edukacja. Aspekty literackie, językowe, aksjologiczne i pedagogiczne (2015), autorka monografii: O prozie literackiej Ewy Nowackiej (2010), Domeny wyobraźni: Andersen i Jung (2015), Dziewczynka z głowa petna bajek. Wielkie tematy w prozie Marty Tomaszewskiej (2019).

e-mail: agnes12@onet.eu 